\title{
PATRICK TOMLIN
}

\author{
TIME AND RETRIBUTION
}

(Accepted 29 July 2013)

\begin{abstract}
Retributivists believe that punishment can be deserved, and that deserved punishment is intrinsically good or important. They also believe that certain crimes deserve certain quantities of punishment. On the plausible assumption that the overall amount of any given punishment is a function of its severity and duration, we might think that retributivists (qua retributivists) would be indifferent as to whether a punishment were long and light or short and sharp, provided the offender gets the overall amount of punishment he deserves. In this paper I argue against this, showing that retributivists should actually prefer shorter and more severe punishments to longer, gentler options. I show this by focusing on, and developing a series of interpretations of, the retributivist claim that not punishing the guilty is bad, focusing on the relationship between that badness and time. I then show that each interpretation leads to a preference for shorter over longer punishment.
\end{abstract}

\section{INTRODUCTION}

Retributivists believe that punishment can be deserved, and that deserved punishment is intrinsically good or important. ${ }^{1}$ In contrast with instrumentalists who believe that punishment, if justified at all, is justified as a necessary evil, ${ }^{2}$ retributivists believe that punishment is justified (at least in part) because we make the world better (in at least one way) when people get what they deserve. Punishment serves the value of retributive justice, and is to be pursued (at least

\footnotetext{
${ }^{1}$ Given the subject of this paper, I should, perhaps, note at the outset that I am not a retributivist, or at least not a committed one. But I am interested in the structure and the consequences of the view especially its implications for other areas of criminal law theory - and the present paper is written in that spirit.

${ }^{2}$ Bentham wrote: 'Punishment itself is an evil, though necessary to prevent greater evils. Penal justice, in the whole course of its operation, can only be a series of evils'. Jeremy Bentham, Theory of Legislation, 2nd Edn (London: Trübner \& Co., 1871), p. 360.
} 
in part) when and because it will further the realisation of that value. $^{3}$

Retributivists care not only about who should be punished and why, they also care about how much punishment people receive. Retributivists endorse proportionality in punishment: whilst violent assaults and breaking the speed limit may both deserve some punishment, a world in which assaults attract less punishment than speeding is retributively unjust. For retributivists, it is controversial what crimes deserve what punishment, and how such deserved punishments can or should be calculated. ${ }^{4}$ For the purposes of this essay it does not matter whether retributivists think that punishments ought to be absolutely or only comparatively proportionate, nor whether the amount of punishment deserved for a crime is fixed by universal morality, local moral sentiment, or local legal rules. Nor does it matter why we should, or are permitted to, criminalize behaviour and thus threaten people with punishment. What matters is that the retributivist endorses the following proposition:

The Retributivist Belief: Within a political community, for any (just) crime $C$ there is some quantity of punishment, or range of quantities of punishment, $P$, that anyone who commits $C$ deserves. It is (in one way) good that those who commit $C$ receive $P$, and, conversely, (in one way) bad when those who commit $C$ do not receive $P$.

Defining retributivism through the Retributivist Belief may be both under-inclusive and over-inclusive in terms of philosophers' selfdescriptions as 'retributivist'. In many ways this is unproblematic - the definition can be stipulative, and my argument can be aimed only at those who endorse, or are tempted to endorse, this belief. I will briefly lay out, however, several positions which are committed to the belief, ${ }^{6}$

\footnotetext{
${ }^{3}$ This definition of 'retributivist' is possibly controversial. As is well-known, retributivism is a broad church (John Cottingham, 'Varieties of Retribution', Philosophical Quarterly 29 (1979): 238-246; Nigel Walker, 'Even More Varieties of Retribution', Philosophy 74 (1999): 595-605). My essay is only aimed at those who endorse what I call 'the Retributivist Belief', which I outline below.

${ }^{4}$ For the difficulties of doing so, see Greg Roebuck and David Wood, 'A Retribution Argument against Punishment', Criminal Law and Philosophy 5 (2011): 73-86.

${ }^{5}$ It is worth noting that the Retributivist Belief is different from (and less demanding than) the Retributive Principle, around which I base much of the discussion in 'Retributivists! The Harm Principle is not for you!' in Ethics (forthcoming).

${ }^{6}$ For most of these positions, one might hold the Retributivist Belief in two different ways. One's ultimate conviction could be that it is an intrinsically good state of affairs that the guilty are punished (and, conversely a bad state of affairs when they are not). Or one's ultimate conviction might be that we ought to punish the guilty, and that it is good when we do what we ought to, and bad when we don't do what we ought to. Following Derek Parfit's taxonomy of egalitarian beliefs, we might call these retributivist theories 'telic' and 'deontic' retributivisms respectively. See Mitchell N. Berman, 'Two Kinds of Retributivism', in R. A. Duff and Stuart P. Green, Philosophical Foundations of the Criminal Law (Oxford: Oxford University Press, 2011); Derek Parfit, 'Equality and Priority', Ratio 10 (1997): 202-221.
} 
and I will explain why I think that those that are not so committed should not be labelled 'retributivist'.

The following types of retributivism (which collectively may be called 'positive reasons retributivisms', since each believes desert to be a positive reason for state punishment) are committed to the Retributivist Belief. First, the kind of 'pure' retributivism, whose chief proponent in recent times has been Michael Moore, will clearly see deserved punishment as just and therefore good. As Moore says, 'punishing the guilty achieves something good - namely, justice and...reference to any other good consequences is simply beside the point'. ${ }^{7}$ Second, fair play retributivists, who focus on the relative positions of criminals and law-abiding citizens, will see punishment as reinstating a just distribution between the criminal and those who have obeyed the law, and will see a just distribution as something good. ${ }^{8}$ Third, those who think that desert is not the whole story of justified punishment but think that it plays a positive role in justifying punishment, will think that deserved punishment is in one way good, regardless of whether it is all-things-considered justified. ${ }^{9}$ Such theorists may either see desert as a necessary but not sufficient condition for justified punishment, or they may see desert as neither necessary nor sufficient, but simply as a consideration in favour of punishment.

Alongside positive reasons retributivists, some people who reject retributivism completely as a reason for state punishment may also be (in a qualified sense) within the ambit of the thesis presented here. We can call these people 'pure evaluation retributivists'. Such people will endorse the Retributivist Belief if they believe that punishment of the deserving has intrinsic value, but deny that the pursuit of that value can justify state punishment. Such a view could consistently be held, for example, by a political liberal who holds retributivism as part of her comprehensive moral doctrine whilst denying that the state ought to act on such doctrines. ${ }^{10}$

\footnotetext{
${ }^{7}$ Michael S. Moore, Placing Blame (Oxford: Clarendon Press, 1997), p. 111. See also: Robert Nozick, Philosophical Explanations (Cambridge, MA: Harvard University Press, 1981), p. 374.

${ }^{8}$ See, for example: John Finnis, 'The Restoration of Retribution', Analysis 32 (1972): 131-135; Herbert Morris, 'Persons and Punishment', The Monist 52 (1968): 475-501; Jeffrie Murphy, 'Marxism and Retribution', Philosophy \& Public Affairs 2 (1972): 217-243; Richard Dagger, 'Playing Fair with Punishment', Ethics 103 (1993): 473-488.

9 See, for example, Douglas N. Husak, 'Why Punish the Deserving?', in his The Philosophy of Criminal Law: Selected Essays (Oxford: Oxford University Press, 2010); and Overcriminalization (Oxford: Oxford University Press, 2008), Chap. 4.

${ }^{10}$ For the classic statement of political liberalism, see John Rawls, Political Liberalism (New York: Columbia University Press, 1993). For more on retributivism and political liberalism, see Matt Matravers, 'Political Neutrality and Punishment', Criminal Law and Philosophy 7 (2013): 217-230.
} 
For those who hold such a combination of views, my arguments here concern which punishments (qua retributivist) they should prefer and not which punishments they think the state should enact.

The group of retributivists who may be excluded from this account are so-called 'negative' or 'limiting' retributivists. This group of theorists claims that desert is a constraint on the use of punishment (or a necessary condition for just punishment), but in no way provides a reason for the state to punish. ${ }^{11}$ These theorists will not endorse the Retributivist Belief provided they also claim that deserved punishment is in no way good, therefore denying that deserved punishment is either a reason to punish or a reason to find intrinsic value in the punishment of the guilty.

I do not think that such theorists are really retributivists, insofar as retributivism is tied to the concept of desert. ${ }^{12}$ It seems conceptually confused to say that criminals deserve punishment but that this supplies no reason why they should receive punishment and no reason to think that punishment of the guilty is in any way intrinsically good. It seems a simple conceptual truth that if you deserve something, then it is in one way positive that you receive it. Imagine sitting on an awards committee, and making a case that Aruna deserves the award. How would you react to your colleague saying 'Oh yes, I completely agree. I absolutely think she deserves the award. But I don't see any reason why she should have it, and there would be nothing good in her getting it'? These would be absurd things to say. To those attracted to something like the negative retributivist view, I think greater clarity would be achieved by dropping references to retributivism and the concept of desert. Something else, such as liability ${ }^{13}$ or rights forfeiture ${ }^{14}$ is surely doing the moral work.

Given the Retributivist Belief, we need to find some way to map quantities of punishment onto a scale of crimes. In order to do this, one of the things we must do is to find a way of working out how

\footnotetext{
11 This characterisation is taken from R. A. Duff, 'Legal Punishment', in Stanford Encyclopedia of Philosophy (2013): http://plato.stanford.edu/entries/legal-punishment/.

${ }^{12}$ Hugo Bedau wrote that 'Retributivism without desert...is like Hamlet without the Prince of Denmark'. 'Retribution and the Theory of Punishment', The Journal of Philosophy 75 (1978): 601-620, at p. 608. Emphasis in original.

${ }^{13}$ See, for example: Victor Tadros, The Ends of Harm (Oxford: Oxford University Press, 2011).

${ }^{14}$ See, for example: Christopher Heath Wellman, 'The Rights Forfeiture Theory of Punishment', Ethics 122 (2012): 371-393.
} 
much punishment a given act of punishment delivers: it's all very well saying 'Crime A must be punished more than Crime B', but we need to know which punishments are 'more punishment' than others. We intuitively know that ten years imprisonment is more punishment than a $\$ 10$ fine, but exactly what the scale is and how it should be calculated is difficult. Here, in only partial answer to this question, I will put forward and rely upon an extremely plausible conjecture: a punishment's total quantity is a function of its severity and its duration. ${ }^{15}$ Duration is how long the punishment lasts for. ${ }^{16}$ Severity will be more controversial, but there are some modes of punishment that are clearly more severe than others. For example, we know that (provided he is relatively normal) punishing Glenn by banning him from participating in crown green bowls is less severe than imprisoning him. This is particularly easy to see since the greater punishment (imprisonment) contains everything that the less severe punishment does (the crown green bowls ban) and more. Therefore, if we keep the duration of punishment constant, to imprison Glenn is to punish him more than to ban him from bowling. Keeping the mode of punishment constant, punishing someone for longer is clearly to punish them more - a ten year prison sentence is clearly a greater punishment than a five year prison sentence under the same conditions. As these examples show, the overall amount of punishment supervenes both on the severity of the punishment and its duration. Call this the Quantity of Punishment Conjecture.

The Quantity of Punishment Conjecture: $P=S \times t$, where $P=$ quantity of punishment, $S=$ severity and $t=$ time.

I hope that the reader will agree that the Quantity of Punishment Conjecture is intuitively plausible. This plausibility can be bolstered further by thinking about what punishment is. Punishment is an experience intentionally brought about by other human beings - it is

\footnotetext{
${ }^{15}$ One way to envisage this claim is to see punishment as a graph, with severity on the y axis and time on the $\mathrm{x}$ axis. The total amount of punishment will be the area under the graph.

${ }^{16}$ Time may also play a complex role in calculating severity. For example, is keeping someone in prison twice as long twice the overall punishment? Or does a given mode of punishment (e.g., imprisonment) become less severe over time, or perhaps more? Is punishing an 18-year old for a year equally as severe as punishing an 80-year old for a year? I won't try to answer such questions here, but many of them depend on what exactly the metric of punishment is - for example do offenders deserve a loss of wellbeing, or liberty? I am grateful to Oxford's Jurisprudence Discussion Group for interesting discussion here.
} 
a combination of action (punisher) and experience (punished). ${ }^{17}$ Since all human actions and all human experiences are temporal they always have a duration, and so punishment will always have a duration. And to experience something for longer, it seems, is to experience more of it (think, for example, of pain, or a loss of liberty). Sometimes it will be difficult to pick out which experience is relevant, and so what the duration of a specific punishment is. ${ }^{18}$ However, given the overall plausibility of the idea that punishments have a duration, I think we have very good reasons to try. I won't try to defend the Quantity of Punishment Conjecture further here.

Here is a plausible assumption about retributivism. Retributivists (qua their retributivism) have no reason to care what combination of $S$ and $t$ makes up $P$. If there is a permissible range of punishments that all give the offender what he deserves, the retributivist, we may naturally think, will be indifferent between those punishments. If banning Glenn from crown green bowling for ten years gives the same overall quantity of punishment as imprisoning him for a month, and that overall quantity corresponds to the amount of punishment that Glenn deserves for his crime, then the retributivist should (at least from the perspective of her retributivism) be equally happy either way. Call this The Indifference Claim.

\footnotetext{
${ }^{17}$ A possible exception is the death penalty, which offers difficulties for the Quantity of Punishment Conjecture. It is clearly extremely severe, but it is hard to tell how long it lasts for, or whether it is experienced (due to the complex metaphysics of death). A plausible duration is how long the person would otherwise have lived for', since they are robbed of their life for that amount of time. (This seems to be implied by 'deprivation accounts' of the badness of death, on which see: Jeff McMahan, The Ethics of Killing (New York: Oxford University Press, 2002), Part 2; John Broome, Weighing Lives (Oxford: Oxford University Press, 2004), Chap. 17.) I won't try to settle such matters here. I will instead focus on punishments that fall short of death.

${ }^{18}$ For example, a Law and Philosophy referee has suggested that it is difficult to tell how long fines last for, and that this a reason to doubt whether the Quantity of Punishment Conjecture captures anything. In terms of how long fines last for, what we care about here is how long it is until the punishment is over in the relevant sense, how long it is until justice has been done. There are two possible views on fines. One is that they are 'over' as soon as they are paid. (In which case, my argument here suggests that retributivists should generally prefer fines, and for them to be paid immediately, since they are very quick forms of punishment.) However, I doubt that fines are 'over' in the relevant sense as soon as they are paid. My own (tentative) view (which I cannot fully elaborate here) is that it is difficult to work out how long fines last for because fines in fact allow the offender to choose the combination of time and severity. In order to see this, we must first think of what the relevant experience of being fined is. It is having less money, which can be seen as either a lowering of living standards/resources or a loss of liberty (for reasons articulated by, among others, G. A. Cohen in 'Freedom and Money', in his On the Currency of Egalitarian Justice and Other Essays in Political Philosophy (Princeton, NJ: Princeton University Press, 2011)). Both a lowering of living standards and a loss of liberty have durations. But since the offender can choose to reduce his standard of living and/or options drastically for a short time ('I won't go out for a month!') or less drastically for a longer time ('I will have one fewer cappuccino per week for two years') then he is able to choose which combination of severity and time he prefers.
} 
The Indifference Claim: (All else equal) retributivists are indifferent between shorter, more severe punishments and longer, less severe punishments. Retributive justice simply requires that we give an offender the overall amount of punishment she deserves $(P)$.

Retributivists may have many reasons to prefer some combinations of $S$ and $t$ over others. For example, they may learn that, since its quirkiness attracts a lot of media attention, banning Glenn from crown green bowls has a greater deterrent effect than imprisoning him. Whether or not the retributivist believes deterrence to have any role in justifying punishment, if one way of giving deserved punishment begets better deterrent effects, thereby lessening harm, retributivists have reason to prefer that way.

Importantly, the retributivist may have a threshold past which they view a punishment as impermissibly severe, and so will reject any punishment above a certain value of $S .{ }^{19}$ For example, flogging someone for ten minutes may be the same overall quantity of punishment as imprisoning them for a month, but, because of respect for persons, retributivists may believe that flogging represents a level of severity or type of punishment which it is impermissible to administer. ${ }^{20}$

Retributivists may also find that quick punishments are less harmful to criminals' family members, ${ }^{21}$ or are cheaper for the taxpayer. But these are not inherently retributivist reasons for preferring some combinations of $S$ and $t$ over others, and the Indifference Claim simply asserts that retributivists will be indifferent between combinations qua retributivists.

In this paper, I will argue that, despite its plausibility, retributivists should, in fact, reject the Indifference Claim. ${ }^{22}$ This is because

\footnotetext{
19 There are two different ways that the retributivist might view impermissibly severe punishments. She may believe that they're not deserved (in which case the punishment is not within the range of deserved punishments, and so may be immediately discounted), or she may believe the punishment is deserved but impermissible (in which case, the Indifference Claim would assert that the impermissible punishment is on a par with other deserved punishments qua retributivist justice, but ruled out for nonretributivist reasons).

${ }^{20}$ For a critical examination of this (commonly held) position, see Kevin Murtagh, 'Is Corporally Punishing Criminals Degrading?', Journal of Political Philosophy 20 (2012): 481-498.

${ }^{21}$ I am grateful to a member of Oxford's Jurisprudence Discussion Group for this observation.

22 Retributivists who endorse strict interpretations of Lex Talionis (who really think, for example, 'an eye for an eye') may reject the Indifference Claim on different grounds, since they may claim that what is deserved is a very particular experience (and therefore deny that a plurality of combinations of $S$ and $t$ can give the offender what he deserves). However, arguably such retributivists would have balked at the Retributivist Belief, since they may deny that there is some quantity of punishment that an offender deserves, but rather some particular experience. For retributivists who endorse laxer interpretations of Lex Talionis, however, there will often be a plurality of possible combinations which meet Lex, and where this is so, I claim, they should prefer those with shorter durations (and therefore more severe modes). For a lax interpretation of Lex, see Jeremy Waldron, 'Lex Talionis', Arizona Law Review 34 (1992): 25-51.
} 
retributivists should not be indifferent over the time taken to punish. Retributivists ( $q u a$ their retributivism, rather than for non-retributivist reasons) should prefer shorter punishments to longer punishments, and thus - in order that $P$ be kept constant - should prefer more severe to less severe punishments. When all else is equal, of the different punishments that give the offender what she deserves, the retributivist should want to see the shortest and severest of the permissible options handed down.

It is important to note that I do not make this claim as a positive or intuitively attractive argument. I am not saying that I think retributivists should prefer more severe punishments because more severe punishments are in themselves morally attractive. Nor am I saying that retributivists actually currently think this, or will welcome this entailment. I am simply saying that I think this logically follows from the Retributivist Belief (which, as I have made clear, I think follows conceptually from the claim that punishment can be deserved).

That retributivists should prefer shorter punishments becomes clear once we switch focus from the positive retributivist claim that deserved punishment is good to the converse claim that not punishing those who deserve punishment is bad. Call this retributivism's 'badness claim'. Once we think about how to understand this badness claim, and in particular its relationship to time, then it becomes clear, on any plausible understanding of the badness claim, that retributivists should prefer the guilty to be punished quickly (and thus severely).

The essay proceeds as follows. In the following section I outline a series of time periods related to punishment. This allows me to restate my thesis with greater clarity. In Sect. III I outline a series of ways to understand retributivism's badness claim - the badness of not punishing the guilty. Perhaps none of these captures the whole truth about the badness of such non-punishment, but the views I articulate are centred around the major candidates for considerations of such badness (and thus the considerations may be combined with one another to define the whole truth). In Sect. IV I will then show how each understanding of, or consideration of, the badness of nonpunishment of the deserving supports quicker over slower punishment. This in turn (since we are aiming to deliver a certain quantity, or range, of punishment - i.e., we are trying to keep $P$ constant) shows that retributivism prefers more over less severe punishments. 


\section{PUNISHING TIMES}

Before we proceed to the main argument, it will be worth distinguishing some different time periods that we can identify in relation to crime and punishment. Being clear about these at the outset will allow me to refer to them as we go along, and will also allow me to restate my central thesis with greater clarity. The different time periods are:

1. Total Time - the time from the commission of the offence to the completion of punishment.

Total Time is comprised of:

2. Time Until Punishment - time from the commission of the offence to the commencement of punishment.

3. Duration of Punishment - time from the commencement of punishment to the completion of punishment (in the relevant sense ${ }^{23}$ ).

My thesis concerns Duration of Punishment. It says that retributivists should prefer the Duration of Punishment to be as short as possible (and, therefore, the severity of punishment to be as large as possible). But it should be observed at the outset that a short Duration of Punishment should be preferred by the retributivist because of the contribution this will make to a short Total Time.

The state's control over the duration of period 2 - Time Until Punishment - is limited. And for the parts that are under the state's control (investigation and trial) there are good reasons to take our time at this stage. ${ }^{24}$ Justice done hastily, after all, is often not justice at all, and retributivists, of course, want justice to be done. ${ }^{25}$ (All else equal - including accuracy of investigation and trial - however, my

\footnotetext{
${ }^{23}$ I have introduced this parenthetical clause since an offender will, for example, 'experience the effects' of prison long after he is released, but if the deprivation of liberty is the relevant experience of imprisonment (the 'metric' of the punishment) then he will no longer being experiencing punishment in the relevant sense, and punishment will have been completed. My thesis is only committed to the view that just punishments have a duration, and is neutral as to how we should measure the duration of any given punishment.

${ }^{24}$ I am grateful to Lucia Zedner and a Law and Philosophy referee for encouraging me to acknowledge this point.

${ }^{25}$ A Law and Philosophy referee has put it to me that such considerations should also lead us to prefer longer and lighter punishments, since we may need to reverse punishments if a miscarriage of justice is discovered later. There are two things to be said here. Firstly, it must be recalled that my claim is an all else equal claim, and differences in the reversibility or compensability of punishments renders things unequal. Secondly, the referee's point actually leads to the conclusion that we should prefer reversible or compensable punishments. It is not obvious to me that these will necessarily be the longer and lighter ones. I will set all complications concerning the accuracy of the criminal justice system aside in what follows.
} 
argument suggests that retributivists should prefer short Time Until Punishment too.) But however long Time Until Punishment lasts, we then arrive at sentencing, and if we are to keep Total Time down, we must keep Duration of Punishment down. This will involve selecting the punishment that delivers the amount of punishment deserved the quickest, which will be the punishment with the highest average $^{26}$ ) severity.

\section{NON-PUNISHMENT OF THE DESERVING}

Retributivists generally present their theories positively. That is, they try to show that punishment is justified when and (at least in part) because it is deserved. Comparatively little attention has been paid to understanding the corresponding claim that not punishing the deserving is bad. This may seem unproblematic - if one claim is the reverse of another, then (it might be thought) it doesn't matter which claim we focus on.

I think that it is important for us to focus on this badness claim in trying to understand retributivism and its commitments. ${ }^{27}$ This is partly because, as I hope to show in this section, there are in fact several ways to understand or interpret the claim that non-punishment is intrinsically bad, and this is hidden from view when focusing on the positive claim. ${ }^{28}$ It is also natural to focus on and interrogate the badness claim, since a lot of the intuitive force of the retributivist position is to be found in the fact that something seems to be amiss when we do not punish wrongdoers. As Victor Tadros (no friend of

\footnotetext{
${ }^{26}$ We can contrast average severity with peak severity. It is average severity the retributivist should focus on. To see the difference, imagine $P$ can be delivered only by very light continuous punishment, taking ten years, or by four short sharp shocks (each lasting a day) but which must be spaced five years apart, such that Duration of Punishment will be twenty years in total. In the latter, the 'peak severity' is higher, but the retributivist will prefer the former, where the 'average severity' is higher (indeed, is twice as severe).

${ }^{27}$ As Lucia Zedner and Hamish Stewart have pointed out to me, one of the most famous passages in penal philosophy appears to present the retributivist badness claim. Kant writes: 'Even if a civil society were to be dissolved...the last murderer remaining in prison would first have to be executed, so that each has done to him what his deeds deserve and blood guilt does not cling to the people for not having insisted upon this punishment'. Immanuel Kant, in Mary Gregor (ed.), The Metaphysics of Morals (Cambridge: Cambridge University Press, 1996), p. 106.

${ }^{28}$ For an excellent example of the questions, issues and ideas that can arise when we switch our focus from a popular claim about goodness to the relevant badness claim, see Larry S. Temkin's investigation of the claim 'inequality is bad', in Inequality (Oxford: Oxford University Press, 1993). As Temkin himself has emphasised, retributivism and egalitarianism have important similarities. See his 'Equality, Priority and the Levelling Down Objection', in Matthew Clayton and Andrew Williams (eds.), The Ideal of Equality (Basingstoke: Palgrave Macmillan, 2002).
} 
retributivism ${ }^{29}$ ) notes, many people become attracted to retributivism, and come to believe in the possibility that making offenders' lives go worse is intrinsically good, by thinking about cases which seem to support the badness claim - cases where punishing a serious moral wrongdoer will do no further good, but where we feel that leaving them unpunished will be morally problematic:

Imagine [writes Tadros] a person who has committed a number of racially motivated murders. And suppose that once this has been discovered and he has been identified, punishing him would have no deterrent effects. Even though he has not been reformed, and continues to believe that he was right to commit his racist murders, we are now sure that he poses no further threat to us. Punishing him, in this case, would appear to lack instrumental benefits. And yet we would not wish him to go on living happily in society, going about his day-to-day business. We would want to see him suffer. ${ }^{30}$

Retributivism, then, receives extensive intuitive support not through thinking about punishing wrongdoers - not through thinking about people rotting away in jail and that bringing joy to our hearts - but rather through thinking about a world in which those who have done serious wrongs are not punished. Since the badness claim seems to be a large part of what is attractive about retributivism, it is perhaps surprising that it has not received more attention.

Here I want to focus our attention on that badness claim. In doing so, I will present a series of interpretations or elaborations of the claim, focusing on the badness of non-retribution's relationship to time. ${ }^{31}$ I will then (in the following section) show how each plausible view nevertheless leads to the rejection of the Indifference Claim.

In order to show that there are a variety of ways in which we can interpret the badness claim, which will help us to establish how bad the non-punishment of a given offender is, I will use the following three cases. In each case, the offender initially commits the exact same crime, and in each case the punishment is just and

\footnotetext{
${ }^{29}$ Tadros, The Ends of Harm, esp. Chaps. 3-4.

${ }^{30}$ Ibid., p. 44.

${ }^{31}$ In his brief discussion of desert and time in his The Geometry of Desert (Oxford: Oxford University Press, 2012), pp. 10-12, Shelly Kagan focuses on time's effect on whether or not we are deserving of something, whereas here I am chiefly interested in the relationship between time and us not getting something that we in fact deserve (though my discussions of identity move us more into the vicinity of Kagan's questions). Similarly, George Sher's discussions of desert and time focus on why it is that the past matters for desert claims and not on how quickly desert should be realised or how to understand the relationship between time and desert not being realised. See his Desert (Princeton, NJ: Princeton University Press, 1987), Chap. 10.
} 
proportionate. Furthermore, all else is equal - all the protagonists have the same length of life, and the same quality of life (other than differences traceable to punishment), and their identities (and what underpins them) do not undergo any kind of change that could render them less deserving of punishment over time.

Andrew is caught and punished immediately. Barbara is only caught and punished fifty years later. Charlotte is never caught or punished. She dies fifty years later.

It will be observed that these cases do not directly engage the issues raised by the Indifference Claim - length and severity of sentence (Duration of Punishment) - since all the punishments (we can imagine) are, once delivered, instantaneous. However, the idea is to use these cases (which focus on Time Until Punishment) in developing a series of understandings of the badness of non-punishment, and its relationship to time. I will then use these understandings to see what retributivists should think about Duration of Punishment, showing that each understanding pushes them toward quicker (and, in order to keep $P$ constant, harsher) punishments.

\section{A. The Brute Time View}

I take it that when we think of cases like Tadros', we are troubled by Barbara- and Charlotte-like cases, in which people who have committed serious wrongs and are then left wandering free and unpunished (in these cases, for 50 years). This may make us think that what is bad about non-punishment is that for a given length of time there is a retributive injustice. This may then lead us to the thought that the badness of non-punishment is to be calculated by the moral importance of punishing the person, and the time that elapses between the punishment-worthy act (when they become deserving of punishment) and the deserved punishment, such that, as long as the person remains unpunished, things keep getting worse. Call this the Brute Time View. The Brute Time View can be supported by the following two plausible propositions.

[1] It is a bad state of affairs when someone who deserves punishment is left unpunished.

[2] A bad state of affairs is worse the longer it goes on.

[1] seems to follow from the Retributivist Belief. To see the plausibility of [2], consider inequality. If we think an inequality is bad, then the 
longer the inequality exists for, the worse things seem to be - an inequality that lasts a generation is worse than one that exists for a day. Or consider demonstrators on a march. It would be odd to hear: 'What do we want?' 'Justice!' 'When do we want it?' 'Who cares?!' The right answer is surely 'Now!' We should, it seems, prefer that justice be done sooner rather than later, and given that retributivist justice won't be done until the offender is caught and punished, it seems that we should also prefer punishment sooner rather than later. ${ }^{32}$

However, the Brute Time View has problems. The first is that it seems to attribute moral significance to time itself (rather than things like human experience - which usually go along with time) and it is hard to see why time itself should have this significance. Imagine that before being pricked by the spinning wheel, Sleeping Beauty commits a horrific crime. She falls asleep for 100 years, and, upon waking, is immediately punished. (We can also imagine that her victim and any other involved parties also fall asleep for 100 years.) Would the passage of time itself make things worse and worse, such that things are worse than Barbara?

The Brute Time View also has the consequence that Charlotte is infinitely worse than Barbara (and Andrew). Since Charlotte dies, and thus will never be punished for her crime, things will keep getting worse as this injustice continues. ${ }^{33}$ It seems plausible to me that Charlotte is worse than Barbara, but it seems implausible that things keep getting worse ad infinitum. ${ }^{34}$ Is it a little worse today than it was

\footnotetext{
${ }^{32}$ It may be thought that the Brute Time View (and the Existing Bad Person View explored below) will only be attractive to those who hold a telic view of retributive justice (see n. 6). Whilst I agree that there is a natural fit between these views and telic retributivism, I think it plausible that a deontic retributivist might endorse one of them. When I have an undischarged duty (and where that duty does not have a temporal component built into it, like promises often do) it seems plausible to believe that (all else equal) the sooner I fulfill my duty, the better.

${ }^{33}$ I assume here that there is no post-death divine retribution. Michael Moore's support for retributive legal institutions is underpinned by his atheism (Placing Blame, p. 152), suggesting that if we believe in divine retribution, we ought not to have retributive legal institutions, as if God exists, we really ought to leave these things to Him, as He will no doubt do a much better job of delivering justice than we do. This is interesting for us here because the In the End View (see below) will agree with Moore, whilst the Brute Time and Existing Bad Person Views will provide reasons (though not decisive ones) for us to punish here on Earth even if there is a God who can punish later. I am grateful to Saul Smilansky for useful comments here.

${ }^{34}$ It is worth elucidating the phrase 'keep getting worse' to avoid a misunderstanding. This is not to say that the injustice is getting bigger (such that more punishment would fix it - modulo the kinds of issues raised at $\mathrm{n}$. 16) but rather that the injustice remains of the same size (and so will take the same amount of punishment to fix), and the longer this goes on, the worse the overall badness of that injustice gets. If we think of a graph, with the y axis as 'retributive injustice', and the $\mathrm{x}$ axis as 'time', then, as we move to the right, the line is flat (i.e., the injustice remains constant), but the area under the graph (the overall badness) is growing. However, it would continue to take the same amount of punishment to reconnect the line with the $\mathrm{x}$ axis. That is the view I am seeking to describe here.
} 
yesterday that Jack the Ripper still hasn't been punished? This seems unlikely. Once the Ripper has died, the badness of not punishing him seems fixed. Things don't get any worse, but the badness of not having punished someone who deserved to be punished remains.

\section{B. The Existing Bad Person View}

We may come to reject the Brute Time View because we think that what seems bad in cases like Tadros' above is that there is an existing person in our society who deserves some punishment and who is not getting it. They (unlike Jack the Ripper or Sleeping Beauty) are going around having a normal life while they should be being punished. Once the deserving person no longer exists, the badness of the situation does not change - there is no longer anyone who deserves punishment walking around not being punished. Proposition [2], above, remains valid, but the badness specified by Proposition [1] is specified in a different way. What matters is not that someone has not been justly punished, but rather that a currently existing, thinking, experiencing person ${ }^{35}$ has not received some punishment he deserves. As this state of affairs persists, things keep getting worse. This gives us a view which we can call the Existing Bad Person View. On this view, the longer a person who deserves some punishment is around in our society and is not punished, the worse things get. This makes Barbara worse than Andrew, and Charlotte worse than Andrew. This seems plausible - it seems likely, as I said before, that the longer some bad state of affairs persists then the worse things are. In Andrew the retributive badness is rectified immediately, whilst in Barbara and Charlotte the badness exists for 50 years.

The difficulty with the Existing Bad Person View is that it suggests that Barbara, in which the deserved punishment is (eventually) delivered, is as bad as Charlotte, even though Charlotte dies blissfully unpunished. In both cases, there was 50 years of the retributively bad state of affairs in which a person who should be punished was walking around unpunished. This bad state of affairs is ended through death in one case and deserved punishment in the other. If that state of affairs and its persistence is what matters in determining the badness of nonpunishment, then the two cases are equally as bad.

\footnotetext{
${ }^{35}$ I include so many (perhaps unnecessary) adjectives in order to separate the normal cases that I mean to capture here from the Sleeping Beauty case.
} 


\section{The In the End View}

If we think that Charlotte is worse than Barbara, then we might be attracted to the In the End View. On the In the End View, what matters is that the deserving are punished in the end. It is bad that the deserving go unpunished, but as soon as they get their just deserts, all is well with the world (from the perspective of retributive justice). On this view, Barbara is better than Charlotte, since Barbara gets her just deserts and Charlotte does not. But on the In the End View Barbara is not worse than Andrew - since both end up getting their just punishment. The In the End View cares that before they become unavailable for punishment (e.g., die $^{36}$ ) those deserving of punishment are punished. It does not care how long it takes for the punishment to come about - time is irrelevant. On this view, what is bad about cases like Tadros' is not that there is someone currently living in our community who has yet to be punished for his crime, but rather that there is a risk that he will not be punished at all, or will be punished insufficiently. Provided he is punished in the end (and proportionately), though, we should be content (from the retributivist perspective).

Like the other two views, the In the End View has some potential problems. As I said before, our demonstrators who care about justice but don't mind when it arrives seem to have an odd position. Consider the families who struggle for years to ensure that justice is done to those who have seriously harmed them or their loved ones. Their desire for justice may have troubling or morally irrelevant psychological bases (such as a desire for revenge or 'closure'), but, from the moral perspective, should they be equally content with justice being done years down the line, rather than at the time of the offence? Would it not be reasonable for them to say that it is preferable, in and of itself, that justice is done sooner rather than later?

None of these three views - the Brute Time View, the Existing Bad Person View, and the In the End View - may, on their own, provide the most attractive or plausible view about the badness of the non-punishment of the deserving. Perhaps the central insights or concerns of some of them should be combined. For example, if retributive justice is a value, and thus not punishing people who

\footnotetext{
${ }^{36}$ I shall explain later some other ways, short of death, in which people may become 'unavailable for punishment'.
} 
deserve punishment is bad, then it seems to me likely that the longer we wait to punish them, the worse things are, since an existing person who should be punished wandering round unpunished is a bad state of affairs (and therefore that Barbara is worse than Andrew) and that it is important that we punish them in the end (and therefore that Charlotte is worse than Barbara). Therefore, some combination of the concerns that drive the Existing Bad Person View and the In the End View may be the best view.

However, for my central thesis here - that retributivists should reject the Indifference Claim - it does not matter if and how these concerns are combined. This is because each view independently recommends the rejection of the Indifference Claim, and, furthermore, each recommends its rejection in favour of shorter, more severe punishments over longer, less severe ones.

\section{THE REJECTION OF THE INDIFFERENCE CLAIM}

In this section I will show that all three of the understandings of the badness of non-punishment and its relationship to time outlined in Sect. III lead the retributivist to preferring short, harsh punishments over longer, less severe ones. You may be wondering how the above section can relate to questions about the length of punishment. After all, the positions developed in Sect. III were developed in response to cases which differed on (a) whether punishment was delivered at all, and (b) if it was, how long it was before it was delivered - they seem to point towards issues around and positions about when punishment should begin (i.e., Time Until Punishment), not how long punishment should last once it's in progress (i.e., Duration of Punishment). How could these positions tell us anything about Duration of Punishment - about whether we should prefer shorter or longer punishments, or, as the Indifference Claim suggests, be indifferent about the length of punishment?

The reason that these theories about the badness of non-punishment and their relationship to time can tell us something about Duration of Punishment is not to be found in the intuitions or cases that led to us, above, developing or endorsing the different views about the badness of non-punishment, but rather what those views, once developed, tell us about the Total Time, and thus (derivatively) about Duration of Punishment. 


\section{A. The Brute Time View}

The Brute Time View says that whilst we are waiting for deserved punishment to be delivered (Time Until Punishment), this is a bad state of affairs, since there is a retributive injustice which is yet to be rectified. The longer this state of affairs persists, the worse things are. Since once we are in the process of punishing someone they nevertheless still deserve some punishment (otherwise we would stop punishing them), then until we have completed the punishment, the bad state of affairs of undelivered deserved punishment remains. Since what we care about, on the Brute Time View, is getting to the stage of having made things retributively just (and thus to have delivered all deserved punishment) as soon as possible, then we should care about how quickly punishment is completely delivered. In other words, we should favour as short a Total Time as possible, and so should favour as short a Duration of Punishment as possible. Indeed, the Brute Time View would prefer a late start to punishment followed by very quick and severe punishment over an immediate start to punishment coupled with long and light punishment - it is focused on when punishment is over, and justice has been done, and getting to that point as quickly as possible.

\section{B. The Existing Bad Person View}

The inference from the Existing Bad Person View to the issue of how quickly (and therefore harshly) deserved punishment should be delivered is less clear. That is because of an ambiguity around what, at root, bothers us about the existing bad person - that there is an existing person who deserves some punishment and has not yet had it, or that there is an existing person who deserves some punishment and is not currently receiving any punishment. Which is a bad state of affairs - that a deserving person has not yet been fully punished, that a deserving person is not yet receiving her punishment, or both? Call the version of the Existing Bad Person View in which the only thing that is bad is that there is an existing person who still deserves punishment the Completion Version, and the version in which the only thing that is bad is that punishment is not yet being delivered the Commencement Version. I will first show what each view implies for the length of deserved punishment retributivists should prefer. I will 
then try to show that the Commencement Version is implausible a concern for when punishment begins is only plausible in combination with a concern for when it ends (the concern behind the Completion Version) and/or a concern for it being delivered in full (the concern behind the In the End View).

The Completion Version clearly recommends quick and severe punishment. On this view, it is bad that some existing person deserves some punishment that they have not yet had, and the longer this state of affairs persists (or is experienced) the worse things get. Therefore, we will want to ensure that the person has all the punishment that they deserve as soon as possible. Even once we are punishing someone, they are a still an existing person who deserves some punishment and so we should aim to complete punishment as soon as possible.

On the Commencement Version, we don't seem to have such a reason to prefer quicker to slower punishment. This view states that what is bad is that some wrongdoer is not currently in the process of being punished, not that they have yet to be punished fully - it is entirely focused on Time Until Punishment. So, provided the punishment begins quickly, retributivists have no reason to prefer any combination of $S$ and $t$ over any other. The attraction of the Commencement Version can be seen when we think of Tadros' case of the racist murderer happily living amongst us, and the sense of injustice that this example engenders. What seems to drive our sense of injustice here is that the person is not being punished. But in order to escape any ramifications for the Indifference Claim, the Commencement Version must stand alone, and not be coupled with concerns about when or if punishment is completed. I will now argue that this is implausible.

Consider two criminals, convicted of the same crime, and sentenced immediately, so both wait the same amount of time before beginning their punishment. Both punishments are deprivations of liberty and are (overall) equal to one another and proportionate to the offence (i.e., satisfy $P$ ). The first offender is deprived of his liberty in the ordinary sense, and is given a year in jail. The other is banned from Birmingham, Alabama (not where he lives, but somewhere he had thought about going to) for one thousand years. On the Commencement Version, these two cases are equivalent, since in both 
the guilty are experiencing punishment after the same amount of time. Should the retributivist, concerned as they are to see deserved punishment delivered, view these two cases as equally satisfactory, and care only about when such punishment begins and not at all about when, if, or how much of it, is actually finally delivered? Are we to care that justice is done, or merely that justice is in the process of being done? The former is surely the more plausible view - and we should therefore care that justice is fully done, or that as much of it is done as possible. We should think the situation retributively unjust while there is still deserved punishment to be delivered, and we should think injustice a bad thing. Given this, the Commencement Version is implausible - it may matter when punishment begins, but such a view should be coupled either with the concerns behind the Completion Version or the In the End View. I have already shown how the Completion Version favours faster punishments, and I will now do the same for the In the End View.

\section{The In the End View}

The In the End View does not, unlike the Brute Time View and the Completion Version of the Existing Bad Person View, say that faster punishments are intrinsically better than slower ones. The In the End View explicitly does not care about how quickly we get from a state of affairs in which someone deserves some punishment to the state of affairs in which this is no longer the case - what matters is that the person gets the punishment they deserve, and so we can take our time punishing them. Therefore, in the following kind of case, the In the End View would endorse the Indifference Claim: Some person deserves some punishment. We can make it last 20 seconds or 10 years, and are sure, either way, that the punishment will be fully delivered.

The problem for the retributivist who wants to endorse the Indifference Claim, however, is that we are never in that situation. Whilst, according to the In the End View, we do not bring about a bad state of affairs by waiting, we will always risk bringing about a retributively unjust state of affairs by waiting, since, in the interim, the person may become unavailable for punishment, such that (some of) their punishment will remain undelivered, and therefore an injustice will exist which cannot be undone. There is, therefore, a 
contingent argument for faster (and thus more severe) punishments from the In the End View.

The most obvious way in which we potentially risk injustice by delaying the full delivery of punishment is that people may die. If a wrongdoer dies, happily unpunished (like Charlotte) then, on the In the End View, this is bad. The longer we leave the full delivery of deserved punishment, the greater the possibility that this bad state of affairs will come about. Even if we begin punishment immediately, people may die once it has begun but before it is completed. So, it seems, we have retributive reasons to ensure the punishment is delivered as quickly as possible, so as to reduce the risk that the person will die before punishment is completed.

Should retributivists worry about those who have yet to receive their full punishment dying before they have received their full punishment? ${ }^{37}$ If, plausibly, death is equal to or, more likely, worse than the most severe form of permissible punishment, then it hardly seems that by 'dying on the job' a prisoner 'escapes' some just punishment. For example, imagine we arrest a 20-year old, and sentence him to 20 years in jail. Either he completes his sentence and then goes on to have 40 more years of a wonderful, happy life, or he dies at 30 , half way through his sentence. He is hardly better off 'escaping' his second 10 years through death!

There are two things to say to this. The first is that even if this is the right way to view things, this will still give us reasons to punish the elderly quickly (and thus severely). The response under consideration states that offenders who die early do not 'escape' punishment but rather are left worse off than if they had lived through their full punishment - how much punishment they deserve can only be calculated within the context of their overall life, including how much suffering they endure other than at the hands of the criminal justice system. However, imagine we have an 80-year old who has committed a serious crime. Given that we know that he has lived for at least 80 years, we know he deserves twenty units of punishment within the context of that overall (full) life. On the In the End View, we have reason to ensure that we get all twenty units in before he goes, and thus to punish him very severely. This implication is, of course, limited in practice, especially since most crime is committed by the young.

\footnotetext{
${ }^{37}$ I am grateful to Saul Smilansky and Victor Tadros for pressing me to address this.
} 
However, and this is the second (and more important) point, it is not clear that what the retributivist should care about is (only) whether or not the offender 'gets off. Only if we think punishment should be purely about deserved suffering, such that the only point of the punishment is that the offender's life goes worse, regardless of how or why that comes about, should we endorse the view that the offender remains sufficiently (or, indeed, over-) punished if he dies early, before serving his full sentence. But this line of thinking has the following four counter-intuitive consequences. First, we should not punish those who, for example, lose an arm in an attack on somebody, if the normal punishment would fall short (in overall terms, in $P$ terms) of the loss of an arm. Second, nor should we punish those whose lives we know will be naturally cut short (and, importantly, we should refrain from such punishment on retributivist grounds, and not on independent grounds of mercy): 'Hey, I know Bob tried to kill you, but he doesn't deserve any punishment - he's got cancer and will die earlier than most'. Third, when, as is normal, we are uncertain as to when someone will die, this gives us a reason to refrain from punishing them at all - it risks overpunishment, as if they are punished and then die early, they will have suffered too much. Fourth, we should regard those who die early having been punished as having been treated unjustly. Any early death should count as punishment or like punishment on such a view.

It seems doubtful that punishment is simply deserved suffering. Do we impose hard treatment on offenders only to ensure that suffering is achieved, whilst being indifferent as to whether we, as a society, shut the door and turn the lock, or whether it is blown closed (for example) by the wind? Many retributivists would deny this. For example, they may think that the hard treatment is delivering deserved censure $^{38}$ or stigma ${ }^{39}$ - a communicative message is delivered through the hard treatment. This isn't to say that the relationship between censure and hard treatment is linear (the hard treatment imposed in the first month in prison may deliver more censure than the fiftieth month), but simply that hard treatment is

\footnotetext{
${ }^{38}$ Andrew von Hirsch, Censure and Sanctions (Oxford: Oxford University Press, 1995).

39 Douglas Husak writes that 'most legal philosophers have come to appreciate that punishment contains not only the element of hard treatment, but also the conceptually distinct component of stigmatization'. Douglas Husak, 'Already Punished Enough', in his The Philosophy of Criminal Law: Selected Essays, p. 437.
} 
the vehicle for censure, such that if you haven't had all your hard treatment, you haven't had all your censure. ${ }^{40}$ Or, retributivists may think that punishment must be, and is valuable as, hard treatment in response to offending, and therefore that it must be imposed and intended suffering, such that a natural death or losing one's hand in an attack simply does not count as punishment, and is not commensurable with it. For these retributivists, then, early death does mean that the offender departs before having had all of their deserved punishment, and the In the End retributivist will see this as in at least one way regrettable. Therefore, all else equal, such a retributivist should prefer quicker punishments (which will therefore be harsher punishments) in order to minimize the risk of the offender shuffling off the mortal coil before justice can be done.

Above, I have distinguished censure and hard treatment, and argued that since censure is delivered through hard treatment, then unless the hard treatment is completed prior to death, the offender won't have been fully censured and thus justice will not have been done. Whilst I believe this understanding of the relationship between censure and hard treatment is the usual one, ${ }^{41}$ there is an alternative understanding available, which appears to avoid my claims about speed and severity of punishment. ${ }^{42}$ I will now present that understanding, and then argue (a) that it is implausible; and (b) that attempts

\footnotetext{
${ }^{40}$ In his thought-provoking essay 'Already Punished Enough', Douglas Husak only considers cases where the extra-legal 'punishments' incorporate stigmatizing elements. Thus, even if Husak is right that extra-legal 'punishment' should sometimes be considered in working out how much punishment the legal system should dispense, he provides no argument in support of early (though natural) death counting as part of the deserved punishment/suffering.

${ }^{41}$ For accounts that appear to treat the relationship between hard treatment and the communicative aspect of punishment in this way (communication through hard treatment, rather than through the promise of, or intention of, hard treatment), see: A. P. Simester and Andreas von Hirsch, Crimes, Harms and Wrongs (Oxford: Hart, 2011), pp. 14-15 (censure is expressed 'through' deprivation); Nozick, Philosophical Explanations, pp. 371-374 (hard treatment 'effects' the necessary reconnection between offender and values); Joel Feinberg, Doing and Deserving (Princeton, NJ: Princeton University Press, 1970), p. 99 (the hard treatment itself 'expresses' condemnation); Michael Davis, 'Punishment as Language: Misleading Analogy for Desert Theorists', Law and Philosophy, 10 (1991): 311-322, at pp. 316-318 (imposed hard treatment 'carries information'); Igor Primoratz, 'Punishment as Language', Philosophy 64 (1989): 187-205, at p. 200 (hard treatment 'translates' condemnation into the currency of self-interest); F. H. Bradley, Ethical Studies (Cambridge: Cambridge University Press, 2012), p. 25 (it is the hard treatment that 'denies the wrong'); A. J. Skillen, 'How to Say Things with Walls', Philosophy 55 (1980): 509-523, at p. 517 (hard treatment is the 'expression or communication of moralistic and punitive attitudes'); A. C. Ewing The Morality of Punishment (London: Kegan Paul, Trench and Trubner \& Co., 1929), p. 84 (hard treatment 'impresses' on the offender that he has done wrong); R. A. Duff, Punishment, Communication and Community (New York: Oxford University Press, 2001), p. 82 (independently of conviction, censure is expressed 'through' hard treatment).

${ }^{42}$ This understanding was put to me, in slightly different ways, by two Law and Philosophy referees and Jeremy Waldron.
} 
to avoid that implausibility lead us back to preferring faster punishments.

This alternative understanding goes something like this. The offender is censured at sentencing, when the state commits to a certain punishment. Censure is then complete, but must be backed up by the promised hard treatment. The hard treatment thus simply reinforces, in some sense, the censure, but does not deliver it. Given this, certain disruptions to hard treatment will undermine the message of censure (and thus create injustice), whilst others will not. If the state chooses to let an offender out early, for example, it 'takes back' the message, and so the censure is undermined. If, on the other hand, the offender dies naturally, the message is not undermined, and so the censure remains complete. Given this, we might think that on this picture once we have done the censuring (and if the censuring is what really matters), we can take our time with the hard treatment. Therefore we can be relaxed about Duration of Punishment.

The first thing to note about this argument is that it still leaves us with retributivist reasons for preferring fast Time Until Punishment (or, more precisely, time until censure), and, possibly, some reason to prefer fast Duration of Punishment. It is still held, on this view, that some disruptions to hard treatment will undo censure. We therefore have good retributivist reasons to minimize the possibility that these disruptions will occur. And it seems likely that the quicker we get the hard treatment over, the less the likelihood that those disruptions will come to pass.

More importantly, I think this picture of the relationship between censure and sanction is incorrect. What this picture seems to require is for the state to (a) censure; and then (b) intend that the offender suffer hard treatment, such that if the offender dies before the completion of hard treatment, this should not trouble us (since the intention was still there). If that is the case though, what is to stop the state setting the punishment as being very, very light and very, very long, such as sentencing a murderer to one thousand years of being banned from Birmingham, Alabama? It will have intended that the offender receive the full hard treatment, but it would have known that he wouldn't. Is the retributivist to be satisfied by murderers receiving very, very light punishments which, were they to be experienced for super-human amounts of time, would constitute the 
deserved punishment, even though more severe punishments were available ${ }^{43}$

It will be objected that in such a case the state's intention isn't a real intention, or that the state's commitment to the offender receiving his (full) hard treatment must be more fulsome in order for the censure to be properly conveyed, since in this case the state knows the offender will never receive his full hard treatment. But if that is the case, the proponent of this view (and who wants to deny that faster punishments are retributively better) finds herself atop a slippery slope - one that, I believe, leads us straight back to faster punishments. Rather than a 1000 year sentence, we could set the punishment to be very light and to be completed when the offender is 110 years old. There is a chance he will live to see the full hard treatment through, even though we know he almost certainly won't. So we can't say the state knows he won't see it through. But this nevertheless seems unsatisfactory - it doesn't feel like the state really means it when it sentences someone to suffer hard treatment it knows he almost certainly won't see through. However, would setting a sentence that was due to be completed when the offender was ninety be satisfactory? Or eighty?

At this point, the proponent of this view (and who wants to resist faster punishments) must do one of two things. One option is to draw a firm line which states exactly how sure the state must be that the hard treatment will be completed for us to be satisfied that the commitment to punish is meaningful enough. Any such line, however, is bound to feel arbitrary. The (more plausible) alternative is to say that in order for the state's commitment to be genuine, then for any two punishments that are otherwise equal, the state should prefer the punishment which is more likely to deliver the hard treatment in full (or at least as much as can be permissibly delivered). In other words, the state will choose the permissible option that will maximize expected hard treatment. This seems right. It seems a fair condition to place on my being committed to something coming

\footnotetext{
${ }^{43}$ That more severe punishments are available distinguishes such cases from those where serious wrongdoers receive, for example, 400 years in prison, as sometimes happens in the United States. First, let us put aside any scepticism we may have over whether such offenders actually deserve 400 years in prison - let us concede that that is the proportionate punishment. In that case, in sentencing the offender to 400 years, the state commits to an amount of punishment it can't possibly achieve. But, on the assumption that prison is the most severe form of punishment permissible, then in delivering the 400 year sentence the state (a) communicates the correct amount of deserved punishment (i.e., tells the truth), and (b) does everything within its power to deliver as much of the promised hard treatment as possible.
} 
about that, if everything else is equal, I will prefer the option which gives the greatest chance of it occurring (or where its occurring in full is impossible or impermissible, that I prefer the option which will bring about as much of it as possible). But if this is right, it means that, all else equal, the state should always prefer faster rather than slower punishments, since faster punishments mean that there is less chance of the offender dying in the interim, and therefore that there is a higher chance that the offender will actually experience the promised hard treatment (or as much of it as possible).

So far, I have focused on death as a way in which people may become unavailable for punishment. There are perhaps other ways in which people may become unavailable for punishment, though they rely on more controversial positions. Derek Parfit, for example, argues that what underpins personal identity is psychological continuousness and/or connectedness (which he calls 'Relation R') and that it is the strength of this relationship between two beings at different points in time, and not identity, that matters for a variety of things, including the deservedness of punishment:

When some convict is now less closely connected to himself at the time of his crime, he deserves less punishment. If the connections are very weak, he may deserve none. ${ }^{44}$

Parfit's view is founded on some controversial metaphysical views about the persistence of personal identity. But we can endorse Parfit's conclusion about the criminal without endorsing his views about identity. Even if we have a physical view of identity, ${ }^{45}$ we could have a Relation R-based view about the persistence of culpability or moral responsibility, and that may still lead us to endorse Parfit's conclusion that the former criminal no longer deserves punishment in the case above. ${ }^{46}$ What does it take to be responsible? Most contemporary compatibilist theories of moral responsibility argue that acquiring responsibility for some action requires us to have a certain attitude toward the action ('real self views'), or to the mental process that

\footnotetext{
${ }^{44}$ Derek Parfit, Reasons and Persons (Oxford: Clarendon Press, 1984), pp. 325-326. More recently Parfit has argued against retributivism. See: On What Matters, Vol. 2 (Oxford: Oxford University Press, 2011), Appendix E. For scepticism about the significance of the 'selves' view to desert, see Sher, Desert, Chap. 9.

${ }^{45}$ For explanation and defence of such a view, see Eric T. Olson, 'Is Psychology Relevant to Personal Identity?', Australasian Journal of Philosophy 72 (1994): 173-186.

${ }^{46}$ For (slightly) more in-depth discussion, see my 'Choices, Chance and Change: Luck Egalitarianism Over Time', Ethical Theory and Moral Practice 16 (2013): 393-407, at pp. 403-405.
} 
produces it ('intellectual process views'). ${ }^{47}$ Since these are necessary conditions for acquiring responsibility, it seems plausible that they will be necessary conditions for retaining responsibility. If we no longer (fully) endorse the action, or are no longer prepared to accept (full) ownership of the mental process that produced it, then perhaps we should no longer be held (fully) responsible for it - and therefore less deserving of any punishment in relation to it.

Much more would need to be said to fully defend such a view. But if we are prepared to accept either the identity-based or responsibility-based story above, then this provides (further) reasons, on the In the End View, to punish people quickly (and thus harshly). Let us begin with a case where the person changes so thoroughly that they no longer deserve any punishment. ${ }^{48}$ We should, for our purposes here, view this as being like death. The person who deserved the punishment has, to all intents and purposes, disappeared before we were able to do justice. On the In the End View, this is bad and one that cannot be rectified, unless the person were to later revert to a 'self who deserves the punishment.

Now take the case where the person becomes less (but not non-) deserving. Imagine an offender deserves twenty units of punishment. He receives ten, and then changes such that he only deserves half the remaining punishment. He is then punished with a further five units. On the In the End View, what matters is that deserved punishment is delivered. On this view, then, it seems that we missed the chance to deliver some deserved punishment - the state has missed its opportunity to do full retributive justice. Upon committing the crime, the person deserved twenty units of punishment, but they never got it. On the In the End View, this constitutes an injustice which cannot be rectified - it is like a partial death before full punishment is imposed. Therefore, since people may die or change, rendering them unavailable for deserved punishment, retributivists who endorse the In the End View of the badness of non-retribution should prefer quick and severe punishments.

These considerations also speak in favour of swift (and thus severe) punishment from the Brute Time View. Since on that view things will keep getting worse as long as deserved punishment

\footnotetext{
${ }^{47}$ See Elinor Mason, 'Recent Work: Moral Responsibility', Philosophical Books 46 (2005): 343-353.

${ }^{48}$ Some of the puzzles regarding fundamentally changed former criminals are discussed in Saul Smilansky, 'Why Moral Paradoxes Matter? 'Tefflon Immorality' and the Perversity of Life', Philosophical Studies 165 (2103): 229-243.
} 
remains undelivered, it is very important to deliver punishment while we have the chance. If people die or change such that they no longer deserve punishment, we have missed our window to punish someone while they deserved it, and things will, therefore, continue to get worse for ever, as the punishment will never be delivered.

If we accept that people may change such that they no longer deserve punishment, then on both the Brute Time and In the End Views, retributivists have reason to punish the person quickly. This is not the only way that we can try to ensure retributivist justice is done, however. We could also do so by trying to ensure that the person does not become unavailable for punishment. In the case of the dying, this means trying to keep offenders alive such that we can squeeze our punishment in before they go. In the case of people changing, however, this will mean trying to ensure offenders do not change. Since if any changes can lead to one being less deserving of punishment they are likely to be positive changes, involving the rejection of criminal acts or the mental processes that produced them, then it is an unattractive feature of Brute Time and In the End retributivist views that they recommend trying to make sure that people continue to have bad features which make them deserving of punishment until they have received all of their deserved punishment. At the least, quick and harsh punishment before change seems more morally attractive then trying to ensure the evil stay evil while we slowly punish them. Furthermore, our ability to control how quick and harsh a punishment is greater than our ability to control how and when people change (or how long they will live). As such, for both moral and practical reasons, In the End retributivists should prefer quick and harsh punishment over trying to ensure that offenders stay deserving of punishment.

\section{CONCLUSIONS}

My central claim in this essay is that retributivists should reject the Indifference Claim - the idea that it is the total amount of punishment that they are concerned with and are thus neutral between different combinations of severity and duration which make up that total quantity. In doing so, I have been able to develop retributivist scholarship, by focusing on the normally neglected retributivist 'badness claim' - that the non-punishment of the guilty is bad. In 
Sect. III I developed a series of interpretations of this claim, and then, in Sect. IV, I was able to show that all these views recommend that deserved punishment should be delivered quickly.

$Q u a$ retributivist, then, the retributivist has reason to prefer shorter and harsher punishments. It will be for individual retributivists to decide how they think retributivist and non-retributivist reasons interact, how strong or important retributivist considerations are in determining the best or most appropriate punishments all things considered, what the relevant non-retributivist reasons are, and to which combinations of $S$ and $t$ the non-retributivist reasons point. However, within retributivism, so far as I can see, these considerations are decisive, since I am not convinced that anything points toward slower, gentler punishments being consistently or inherently retributively better. ${ }^{49}$ The fastest and most severe deserved punishment will generally be retributively best.

\section{ACKNOWLEDGMENTS}

I first began to think about these issues when employed by the AHRC-funded Preventive Justice project at the University of Oxford (ID: AH/H015655/1), which I worked on with Andrew Ashworth and Lucia Zedner. I am grateful to the AHRC for funding the project, and to Andrew and Lucia for the opportunity to participate in it, for the crash course in criminal law theory, and for comments on the present paper. I have also benefited from written comments from Saul Smilansky and discussion with Oxford's Jurisprudence Discussion Group and Department of Politics and International Relations. I am most grateful to three anonymous reviewers for extensive comments.

\section{OPEN ACCESS}

This article is distributed under the terms of the Creative Commons Attribution License which permits any use, distribution, and reproduction in any medium, provided the original author(s) and the source are credited.

Department of Politics and International Relations

University of Reading, Whiteknights, Reading, RG6 6AA, UK

E-mail: p.r.tomlin@reading.ac.uk

\footnotetext{
${ }^{49}$ I noted earlier that a possible contender is making sure that punishments are as reversible or compensable as possible, but this doesn't necessarily point toward slower punishments. Another possible option is that some more severe punishments may increase the possibility of early death, which would count against them on any retributive view in which the completion of punishment matters.
} 